Кухарук О. Ю., м. Київ

\title{
КОНФЛІКТНЕ МИСЛЕННЯ І КОНФЛІКТНА ВЗАЕМОДІЯ: СОЦІАЛЬНО-ПСИХОЛОГІЧНІ ОСОБЛИВОСТІ ВЗАЕМОДІЇ ВІЙСЬКОВИХ І ЦИВІЛЬНОГО НАСЕЛЕННЯ
}

Описано основні конфліктні настановлення і стратегії конфліктної взаємодії, що виникають між цивільним населенням та військовими і ветеранами. За допомогою емпіричного дослідження виявлено основні зони конфліктної взаємодії, основні конфліктні настанови військових щодо цивільних і цивільних щодо військових. На основі даних фокус-групових досліджень зроблено низку висновків про особливості конфліктів, які можуть виникати між особами, що мають досвід участі у війні, і цивільним населенням. У ставленні до воєнного досвіду з боку суспільства зауважено стигматизацію, героїзацію і бажання відокремити події і досвід війни від мирного світу, з боку військових - переконання щодо того, що цивільні знецінюють їхній досвід, уникають тем війни, не відчувають загрози і $є$ непоінформованими щодо воєнної тематики. Визначено основні стратегії поведінки в конфліктах цивільних і військових: цивільні зазвичай більш активні, застосовують більшу кількість можливих стратегій вирішення конфліктів, військові ж частіше проявляють пасивну агресію та обирають уникання. Описано основні спільні настановлення військових і цивільних щодо війни і військових: визнання військових і їхньої ролі в захисті країни; розуміння необхідності взаємної адаптації, пристосування одних до одних; визнання того, що ці непорозуміння $\epsilon$ i їх треба розв'язувати; запит на поінформованість і медіаграмотність; запит на чіткі “правила гри” щодо всього спектру соціальної взаємодії - від ставлення держави до учасників АТО і надання їм пільг до оформлення паспортів; спільні уявлення щодо конфліктів (щодо чиновників, ролі держави і т. ін.). Обстоюється думка, що конфлікт між учасниками війни та цивільним населенням може бути спричинений різним ставленням до переживання досвіду війни. Описано специфіку досвіду участі у війні, наголошено на його подвійній психологічній природі - травматичній і ціннісній. Виявлено основні відмінності в настановленнях щодо цього досвіду: для цивільних це травматичний досвід, якого не має бути в мирному світі, для військових - травматичний досвід, що має цінність як досвід важливого етапу життя.

Ключові слова: конфлікт, соціальні настановлення, стратегії розв’ язання конфліктів, конфліктна взаємодія, досвід переживання війни.

Постановка проблеми. Вплив війни на умовно мирний, віддалений від неї світ має багато вимірів. Один із них - взаємодія між людьми, що не мають стосунку до активних бойових дій, і тими, хто був залучений до захисту Батьківщини від російського агресора. На жаль, взаємодія між цими двома групами часто сповнена напруженості, аж до 
прямих сутичок і конфліктів. Певна річ, більшість цих конфліктів не можна пояснити приватними, особистісними інтенціями, оскільки вони мають більш загальне, соціальне підгрунтя. Кожен, хто живе в Україні, має свої настановлення щодо участі у війні, адже війна - це не те, що можна ігнорувати і не помічати. Ці настановлення можуть бути різні: активна участь, активна підтримка, пасивне схвалення/несхвалення, уникання, заперечення війни. У переліку цих настановлень уже закладений конфлікт. Цей конфлікт приречений бути активним і гострим. Додатковий конфліктогенний фактор - прояви гібридної інформаційної війни, розв'язаної російським агресором. Зазначений конфлікт $є$ багатовимірним i потребує всебічного дослідження, у т. ч. і засобами соціальнопсихологічної науки.

Аналіз останніх досліджень і публікацій. В Україні та світі активно досліджують тему гібридної війни і іï впливу на суспільство та особистість. Найбільш поширеною є тематика, що стосується прямого впливу бойових дій на безпосередніх учасників. Досліджують передусім клінічні психічні розлади, які можуть бути спричинені війною (Srinivasa, \& Lakshminarayana, 2006), особливості адаптації військовослужбовців до мирного життя та умови іï успішного перебігу (Сайтс, 2013), вивчають різноманітні фактори, що впливають на особисту успішність та соціальну абілітацію ветеранів і військових (МакГоннел, 2009).

Нині посилено вивчають зміни, які виникають у мисленні i світогляді людей, що безпосередньо були залучені до воєнних дій. Підходів до опису можливих змін $\epsilon$ наразі дуже багато. Як приклад можна згадати класичну роботу D. Grossman "On killing” (1995), у якій описано зміни, біологічні, психічні та психосоціальні, що відбуваються внаслідок участі людини в активних бойових діях, коли вона вбиває супротивника, ворога. Ще одним класичним прикладом може бути дослідження Robi Friedman (2015). Для називання змін у світогляді вояка психоаналітик пропонує термін “матриця солдата". У такому підході зміни, які виникають, описуються мовою психоаналізу.

Закономірно, що найбільше уваги дослідники приділяють питанням впливу війни на осіб, які перебувають у зоні бойових дій. Значно рідше вивчають вплив кризової події на осіб, що ії переживають, але перебувають поза зоною конфлікту.

Особливо зріс інтерес до цієї теми в США у 60-70-х роках $\mathrm{XX}$ століття. У цей час гостро постала проблема ставлення до ветеранів війни у В'єтнамі. Негативне сприйняття війни в суспільстві транслювалося на ветеранів і проявлялось в агресивному, зневажливому й осудливому ставленні до ії учасників. Це не в останню чергу спричинилося до виникнення значних проблем, пов'язаних із соціальною адаптацією ветеранів до мирного життя. Одним із підсумків суспільної дискусії навколо цієї теми 
став заклик відділяти ставлення до ветеранів війни від ставлення до війни (Armstrong, McDonough, \& Savage, 2015).

На сьогодні серед актуальних українських досліджень можна назвати роботу В. Васютинського, яка стосується стратегій адаптації спільнот до умов невизначеності (2017). Аналізуючи наявні дослідження, можна зробити висновок, що безпосередньо тема конфліктів між цивільним населенням і військовими, що мають досвід участі у війні, фактично не вивчена.

Невирішеною частиною загальної проблеми впливу війни на цивільне життя $є$ передусім потреба соціально-психологічного аналізу конфліктних настановлень та конфліктної взаємодії між особами, що мають досвід війни, і тими, хто такого досвіду не має.

Мета статті: визначити конфліктні настановлення та стратегії поведінки в конфліктах між цивільними і військовими.

Виклад основного матеріалу дослідження. У 2017 році було проведено соціально-психологічне дослідження "Альтернатива конфліктам і насильству”. Дослідження здійснювалося в рамках проекту “Подолання соціальних наслідків конфлікту на Донбасі та незаконної анексії Криму за допомогою державних структур в Україні та громадянського суспільства", який виконує канадська неурядова організація "Stabilization Support Services" (керівник проекту - Г. Циганенко, дослідники - О. Кухарук і О. Овчар). Одним з етапів проекту був якісний етап: проведено шість фокус-групових досліджень у різних регіонах України з участю цивільного населення і військових. Географія дослідження: м. Біла Церква Київської області, м. Львів, м. Торецьк Донецької області. Три фокус-групові дискусії було проведено з участю військових (по 10-15 осіб у кожній дискусії) і стільки ж - 3 участю цивільних (10-12 осіб у кожній дискусії). Цивільні обиралися випадковим чином, військові - за принципом участі в бойових діях та перебування на службі на час проведення дискусії.

Досліджувалися конфліктні настановлення, що виникають під час взаємодії цивільних і військових. Можливі сфери появи та прояву таких настановлень і спричинених ними конфліктів визначалися на основі попереднього аналізу матеріалів у засобах інформації та публікацій у соціальних мережах. Було визначено, що найбільше проблемних, конфліктних комунікацій у ветеранів з органами державної влади (зокрема щодо пільг), з особами з близького соціального оточення (знайомими або незнайомими), а також у сім'ї та з найближчим колом рідних. Навколо цих трьох рівнів взаємодії і зосереджувалися фокус-групові обговорення. На основі аналізу результатів цих обговорень було виявлено конфліктні настановлення, які представники груп мають щодо інших (цивільні - щодо військових, військові - щодо цивільних). 
У ставленні ииивільних до військових:

1. Військових, що брали участь у бойових діях, часто сприймають як “інакших", “хворих”. Гіпотетична психологічна травма та/або особистісні зміни, які, на думку цивільних, відбуваються через досвід використання зброї, викликають острах, негативне сприйняття і постійний акцент на потребі реабілітації.

2. Військові - “люди у формі” - образ та уособлення війни, а тому можуть викликати сильну емоційну реакцію - позитивну або негативну. I позитивні, і негативні реакції пов'язані з підвищенням рівня тривоги та емоційного збудження, оскільки цивільні змушені згадувати про війну в країні.

3. Військові іноді викликають дуже суперечливі оцінки у цивільних, які не знають, як до них ставитись. Збірний образ військового - це уособлення захисту і героїзму. Але іноді поведінка окремих "осіб у формі” радикально суперечить цьому образу. У ході дискусії було згадано, що в засобах масової інформації подаються сюжети про військових, що вчинили кримінальні злочини під час служби, поводились агресивно, зловживали алкоголем або психоактивними речовинами. Під час обговорення згаданих явищ учасники наводили власні спостереження. Ці негативні явища викликають у цивільних нерозуміння, невизначене ставлення, розгубленість, адже у військових хочуть бачити не лише захисників, а й утілення еталонної, ідеальної поведінки та громадянської позиції.

За результатами фокус-групової дискусії було узагальнено певні проблемні настановлення у ставленні військових і ветеранів до иивільного населення, що проживає поза зоною проведення АТО/ООС:

1. Цивільні не відчувають воєнної загрози, не знають, що таке війна і нічого не хочуть про неї знати. Це досить поширене серед військових настановлення мало яскраво негативне забарвлення, викликало у військових, учасників групової дискусії, почуття зневаги та осуду.

2. Цивільні часто не уявляють, у чому полягає робота військового і як "відбувається" сама війна. Військові відзначали слабку поінформованість цивільного населення щодо цих питань. Вони стверджували також, що ця необізнаність спричинена небажанням цивільних занурюватись у тему війни і є свідченням їхньої байдужості до війни і роботи військових.

3. Цивільні, на думку військових, втратили страх війни і не відчувають іiі як реальну щоденну загрозу. А це призводить до знецінення роботи військових та їхнього значення в житті країни. Таке настановлення викликало переважно агресивну реакцію серед учасників-військових.

У ході дослідження було визначено найпопулярніші стратегії розв'язання конфліктів, які виникали в ході міжгрупової взаємодії і стосувались означених дражливих тем:

1. Цивільні в конфліктних ситуаціях схильні використовувати більший набір можливих стратегій розв'язання конфліктів: перевести діалог у 
мирне річище; написати скаргу, звернутися до керівництва, журналістів або ж на "гарячу лінію”; бюрократично “задавити” чиновників, подаючи разом із документами цитати з нормативних актів; дати хабар. Загалом спостерігається більша готовність відстоювати свої інтереси, менше розчарування і віра в можливість розв'язання конфлікту на свою користь. У безпосередньому міжособовому конфлікті з військовими цивільні найчастіше виявляли готовність відступити. А також певну невизначеність між героїзацією і стигматизацією (настановлення уникати конфлікту, бо військовий має травму війни і через це непередбачуваний).

2. Військові пропонували менший набір стратегій розв'язання конфліктів. Основна стратегія військовослужбовців - уникання конфліктів. Найбільш прийнятний спосіб взаємодії - словесні образи і відмова продовжувати конфліктну взаємодію. Крім того, військові частіше використовували мову агресії: “повідкручувати голови”, “взяти в руки автомат”, “рознести все”. Разом з тим реальних стратегій розв'язання проблеми пропонувалося дуже мало - як і реального втілення озвучених погроз. Отже, спостерігається переважання пасивно-агресивних стратегій в умовах значної емоційної зарядженості взаємодії.

Одним із завдань дослідження було визначення не лише конфліктних настановлень та стратегій поведінки у конфліктах, а й настановлень, що є спільними для обох груп. Стосуються ці настановлення міжгрупової взаємодії та оцінки подій, що відбуваються в країні. Серед основних спільних настановлень, що демонструвалися в ході групових дискусій, були такі:

1. I військові, і цивільні учасники фокус-групових дискусій, безумовно, визнавали, що можливість спокійно жити мирним життям $є$ заслугою військових, які захищають Україну від російської агресії. Емоційна реакція, пов'язана з визнанням цього факту, була дещо сильнішою в групі військових. Проте за змістом такі уявлення у військових і в цивільних збігалися.

2. Обидві групи опитуваних виявляли розуміння необхідності адаптації військових до мирного життя після участі в бойових діях. Також висловлювалося розуміння необхідності взаємного пристосування.

3. Найбільш конструктивним було визнання як військовими, так i цивільними наявності конфліктів, розуміння їх деструктивного впливу та запит на взаємне порозуміння.

4. В обох групах виразно простежувався запит на поінформованість i медіаграмотність. Визнавалася недостатність i необ'єктивність інформації, що спричинює погіршення комунікації.

5. Спільним в учасників фокус-групових дискусій був запит на напрацювання норм міжгрупової взаємодії, які б сприяли визначенню позицій, ролей та взаємодії. Такі норми і правила мали б стосуватися дуже 
широкого кола тем: від ставлення держави до воїнів АТО/ООС і пільг до оформлення паспортів.

6. Учасники продемонстрували схожі уявлення щодо невизначеності ролі держави в провокуванні конфліктів (досі немає належної інформаційної політики, чіткого алгоритму призначення і виділення пільг, механізмів соціального захисту). Було наголошено, що таку позицію органи державної влади займають не лише щодо військових, а й щодо більшості громадян країни. Відповідно, спільний запит на зміни був однією із тих тем, які найбільше об'єднують громадян.

Аналізуючи стенограми групових дискусій, окрім виділених вище особливостей конфліктної взаємодії, ми простежили ще одну дуже важливу тему. Остання є наскрізною для таких обговорень і спричинює непорозуміння та конфлікти. Ідеться про ставлення до наслідків участі в бойових діях для психіки людини. У ході дискусії як в одних, так і в інших групах спостерігався широкий спектр настановлень та емоційних реакцій щодо означеної теми. 3 боку цивільних часто простежувалося нерозуміння того, що відбувається з учасниками бойових дій, у змісті їхніх настановлень виявлялася схильність до стигматизації, а емоційне забарвлення сприйняття було негативним (роздратування, злість, розгубленість). Зокрема, значної популярності набув образ “неврівноваженого героя” - вояка, який робить надважливу справу, але при цьому однозначно є травмованим i перед тим, як повернутися до мирного життя, повинен бути обстежений, пролікований і достовірно визнаний психічно здоровим.

Серед військових також спостерігалася самостигматизація, проте зайвої героїзації не було. Як і не було тотального визначення всіх, хто воював, такими, що мають проблеми із психічним здоров'ям. Про власний досвід участі у війні учасники розповідали як про важливий та значущий, хоч і важкий у переживанні. Ставлення до досвіду участі в бойових діях та його наслідків для психічного здоров'я можна визначити як одне 3 головних конфліктних настановлень у міжгруповій взаємодії.

Більш глибоке розуміння суті конфлікту між військовими i цивільними може дати аналіз особливостей бойового досвіду та його впливу на психіку. I тут спостерігається дещо парадоксальна картина: особа, яка воювала, отримує одночасно два значущих і надсильних за своїм впливом на психіку типи життєвого досвіду. Перший - участь у війні як у випробуванні, де $є$ можливість проявити себе та засвоїти низку ресурсних важливих, екзистенційних цінностей (побратимство, чесність, відвага, правда, подвиг). Цей список можна доповнити багатьма іншими почуттями та особистісними проявами, які здаються пафосними і недоречними в цивільному житті, але є абсолютно природними на війні. Маючи справу із цими екзистенційними цінностями в піковому їх прояві, вояк здобуває значущий досвід, отримати який у цивільному житті практично неможливо. 
Цивільна людина стикається з питаннями життя і смерті всього кілька разів протягом життя, а з такими явищами, як побратимство чи подвиг, може, й узагалі ніколи. Для військових цей ресурсний важливий, екзистенційний досвід стає цінністю сам по собі. I тут спостерігаємо певний парадокс воєнного досвіду: ресурс є водночас джерелом травми. Адже, крім екзистенційних переживань, $є$ й інші закони функціонування психіки - реакції на виснаження, переживання втрати чи травматичної події, яка становить загрозу для життя чи здоров'я. Ці негативні, травматичні явища також $є$ досвідом, що має значний вплив на світогляд та психічне здоров'я.

Переживання негативних впливів війни спричинює саме ті розлади психіки, до яких насторожено, а то й із неприйняттям ставляться цивільні. Серед таких розладів - ПТСР, розлади адаптації, розлади тривожного спектру, зловживання психоактивними речовинами, агресивність та ін. Маємо ситуацію, коли формуються означені вище настановлення: участь у війні призводить до негативних, неприйнятних для суспільства змін у психіці, а тому перед поверненням військові потребують лікування чи діагностики, які б гарантували безпеку мирному населенню. Негативного забарвлення таким настановленням додає й те, що рівень обізнаності щодо війни та особливостей бойових дій є критично низьким, а рівень деструктивності інформаційних повідомлень - критично високим. Тому думка про те, що всі повертаються хворими, агресивними, нездоровими і 3 жагою до вбивства, $є$ дуже поширеною.

Разом 3 тим, як показали результати фокус-групових дискусій, спостерігається і самостигматизація військових, яка набуває досить своєрідної форми. 3 одного боку, військові часто вважають, що 3 ними щось не так, що вони мають певні проблеми та зміни в поведінці, а $з$ другого - армійська культура розглядає звернення по допомогу до фахівців із психічного здоров'я як слабкість. Через унікальність свого досвіду, неготовність суспільства сприймати війну та ії учасників ветерани іноді почуваються відторгненими від суспільства, що призводить до проявів пасивної агресії, звернення до стратегій уникання та складнощів у взаємодії із цивільним населенням. На жаль, наразі доводиться констатувати низький рівень поінформованості військових про ті загрози, які можуть виникати для психічного здоров'я внаслідок участі в бойових діях. Тож зміни в стані психічного здоров'я сприймаються як закономірні, але не дуже зрозумілі - пояснити, що саме відбувається, військові часто не можуть. При цьому власний досвід участі в бойових діях та служби $є$ для них дуже цінним, а тому спроби цивільних його знецінити сприймаються агресивно.

Висновки. Гібридна війна породжує новий тип конфліктів i конфліктного мислення - конфлікти між військовими і цивільними. Ці конфлікти виникають унаслідок низки конфліктогенних настановлень, що 
виробляються у військових і в цивільних. Стосуються такі настановлення взаємного сприйняття групами одна одною і виникають через взаємне упереджене ставлення. Однією із причин конфліктів є специфіка пережитого військовими досвіду: безпосередня участь у бойових діях, значущість цієї участі, неготовність суспільства прийняти й належним чином оцінити такий досвід.

У подальшому є необхідність зосередити увагу на об'єднавчих настановленнях для профілактики конфліктів між військовими і цивільним населенням.

\section{Список використаних джерел}

Васютинський, В. (2017). Індивідуальні і колективні стратегії адаптації мешканців міських громад до життя в період воєнного конфлікту. Проблеми політичної психологіï, 5 (19), 43-52.

МакГоннел, О. (2009). Методическое пособие программы самоуправления ПTCР для солдат LCSW. Взято из http://psyservice.org/wp-content/uploads/ 2015/03/самоуправление

Сайтс, К. (2013). Синдром войны. О чем не говорят солдаты. Москва: Альпина нон-фикшн.

Armstrong, N., McDonough, J. D. Jr., \& Savage, D. (2015) Community driving impact. The case for local, evidence-based coordination in veteran and military family services and the americaserves initiative. Syracuse University, The institute for veterans and military families.

Friedman, R. A. (2015). Soldier's Matrix: A Group Analytic View of Societies in War. Group Analysis, vol. 48, is. 3, p. 239-257.

Grossman, D. (1995). On killing: the psychological cost of learning to kill in war and society. Boston - New York - Toronto - London: Little, Brown and Company.

Srinivasa, M. R., \& Lakshminarayana, R. (2006). Mental health consequences of war: a brief review of research findings. World Psychiatry, 5 (1). Retrieved from https://www. ncbi.nlm.nih.gov/pmc/articles/PMC1472271/

\section{References}

Vasiutynskyi, V. (2017). Indyvidualni i kolektyvni stratehii adaptatsii meshkantsiv miskykh hromad do zhyttia v period voiennoho konfliktu [Individual and collective strategies of adaptation residents of urban communiities to life in the period of military conflict. Problemy politychnoi psykholohii, 5 (19), 43-52. (in Ukrainian)

McHonnel, O. (2009). Metodicheskoye posobiye programmy samoupravleniya PTSR dlya soldat [Methodical manual PTSD government program for soldiers]. Retrieved from http://psyservice.org/wp-content/uploads/2015/03/самоуправлениепосттравматическим-стрессовым-расстройством-ПТСР-для-солдат.pdf [downloaded 9 December 2016] (in Russian)

Sites, K. (2013). Sindrom voyny. O chem ne govoryat soldaty [The Things They Cannot Say: Stories Soldiers Wont Tell You About What Theyve Seen, Done or Failed to Do in War]. Moscow: Alpina non-fikshn Publ. (in Russian)

Armstrong, N., McDonough, J. D. Jr., \& Savage, D. (2015) Community driving impact. The case for local, evidence-based coordination in veteran and military family 
services and the americaserves initiative. Syracuse University, The institute for veterans and military families.

Friedman, R. A. (2015). Soldier's Matrix: A Group Analytic View of Societies in War. Group Analysis, vol. 48, is. 3, p. 239-257.

Grossman, D. (1995). On killing: the psychological cost of learning to kill in war and society. Boston - New York - Toronto - London: Little, Brown and Company.

Srinivasa, M. R., \& Lakshminarayana, R. (2006). Mental health consequences of war: a brief review of research findings. World Psychiatry, 5 (1). Retrieved from https://www. ncbi.nlm.nih.gov/pmc/articles/PMC1472271/

\section{Olha Yu. Kukharuk. Conflict thinking and conflict interaction: socio- psychological peculiarities of interaction between the military men and civilians}

The article describes the main conflict attitudes and strategies of the conflict interaction, which occur between the civilians, military men and veterans. The findings of the empirical study enabled to identify the major zones of conflict interaction and the key conflict attitudes of the military men towards the civilians and those of the civilians to the military men. The outcomes of the focus group surveys prove a number of conclusions about the peculiarities of the conflicts that might occur between the individuals having experience of participation in military actions and civilians. The author states that the attitudes of the society to the war experience is characterized by stigmatization, glorification and a desire to separate military events and war experience from peaceful life. The military men believe that the civilians underestimate their experience, avoid discussions about the war, do not feel any threat and are not informed about the war. The article presents the main strategies of behavior of the civilians and military men in the conflict situations. The civilians are usually more active and employ a bigger number of possible conflict resolution strategies, but the military men more often manifest passive aggression and resort to avoidance. The main shared attitudes to the war among the military men and civilians are recognition of the military men and their role in the defense of the country, awareness of the need for mutual adaptation and adjustment to each other, recognition of misunderstandings and the need to find solutions. There is also a request for information and media literacy, clear "rules of the game" regarding the whole range of social interaction starting from the attitude of the state to the ATO participants and providing them with benefits to processing their passport applications. Both parties also share attitudes to conflicts, civil servants, role of the state and other issues. The author argues that the conflict between the war participants and civilians may be caused by different attitudes to the war experiences. Therefore, the description of the peculiarities of the experience of participation in the military actions has been provided.Special emphasis has been placed on its dual psychological nature, which is both traumatic and valuable. The key differences in the attitudes to that experience can be explained by the fact that for the civilians it is a traumatic experience that should not be encountered in the peaceful life, and for the military men it is a traumatic experience that has its value as the experience of an important phase of their life.

Key words: conflict, attitudes, strategies of conflict resolution, conflict interaction, war experiences. 